|Esi Hairani, NadjematuL Faizah, Muzayyanah, NNur Izzah

\title{
KOHESI METODE TAMYIZ DALAM PELAJARAN BAHASA ARAB DI PESANTREN TAKHASSUS BAYT TAMYIZ INDRAMAYU
}

\author{
Esi Hairani, Nadjematul Faizah, Muzayyanah, Nur Izzah \\ IIQ Jakarta \\ misykat_iiq@yahoo.com
}

\begin{abstract}
Abstrak
Diversitas metodologi dalam mempelajari bahasa Arab dan aspek terkait lainnya telah banyak diproklamirkan oleh beberapa cendikiawan, mulai dari metodologi yang bersifat klasik (metode iqra', qira`ati, baghdadi, al-barqi, maisura, amsilati) hingga metodologi yang berbasis elektronik). Dan salah satu metode yang masih eksis sampai saat ini adalah metode Tamyiz yang diaplikasikan pada pembelajaran teori dasar nahwu-shorof di Pesantren Takhasus Bayt Tamyiz di Indramayu. Hasil penelitian ini diketahui bahwa metode Tamyiz memiliki pebedaaan dengan metode bahasa Arab lainnya, yaitu dengan mempelajari segala hal tentang bahasa Arab dengan hanya memformulasikan teori dasar nahwu-shorof quantum dengan cara pembelajaran yang mudah (easy) dan menyenangkan (fun), adapun langkah metodis dalam metode Tamyiz adalah sebagai berikut : pertama, menghadirkan guru dalam kelas sebagai fasilitator, kedua, metode Tamyiz tidak ada ijazah, dikatakan mampu adalah dengan mengajarkan para juniornya dengan dimonitoring dan evaluasi dari Ustadz, ketiga, memaksimalkan metode menghafal dan mengulangnya, keempat, dielaborasi dengan metode madkhal, manhaj, kelima, tutorial sebaya atau teknik scaffolding atau gunakan kawan sesama murid yang lebih ahli sebagai guru, keenam, kelas formal SMP dibagi berdasarkan jenjang semester kurikulum nasional pendidikan dan dipisah dalam waktunya lalu dilakukan tamyiz tersendiri, ketujuah, metode pembelajaran Tamyiz juga aplikasikan pada mata pelajaran umum lainnya, dan kedelapan, tamyiz Icon Indramayu masih belum optimal karena tidak mengikuti sistem pembelajaran Tamyiz sesuai dengan apa yang telah digariskan oleh penemu metode Tamyiz Abaza, MM.
\end{abstract}

Kata Kunci : Tamyiz; Kohesi; Bahasa Arab; Pesantren 


\section{A. Pendahuluan}

Al-Qur'an kitab transenden bagi umat Islam, dan hukum berlaku secara personal, sosial dan universal, bagi umat Islam maupun umat seluruh alam. Al-Qur'an ditulis dengan bahasa Arab, sehingga membutuhkan ilmu untuk membaca, menghapal dan memahaminya. Idealnya, umat Islam harus mampu membaca al-Qur'an dengan baik dan benar, serta memahami isi dan kandungannya. Namun, tidak semua umat Islam bisa membaca pada taraf memahami isi serta kandungan Al-Qur'an. Oleh karena itu, di sekolah-sekolah yang ada di Indonesia berdasarkan pada peraturan perundang-perundangan mulai tingkat dasar sampai pendidikan tinggi, mata pelajaran agama wajib secara nasional untuk dipelajari.

Salah satu metode dalam mempelajari Al-Qur'an sekaligus bahasa Arab adalah metode Tamyiz. Metode ini menarik karena memiliki deferensiasi dengan metode bahasa Arab lain, yaitu dengan mempelajari segala hal tentang bahasa Arab dan dengan memformulasikan teori dasar nahwu-shorof quantum dengan cara pembelajaran yang mudah dan menyenangkan. Output dari metode ini adalah mampu membuat anak Sekolah Dasar (SD) atau Madrasah Ibtidaiyah (MI) dan siapapun yang bisa membaca Al-Qur'an dengan target sangat sederhana yaitu pintar membaca, mentarjamah dan menulis (imla') Qur'an dan Kitab Kuning dalam waktu 100 jam.

Metode Tamyiz adalah sebuah hasil riset yang akan menyebar kepada masyarakat, untuk muslim Indonesia maupun muslim dunia, dan telah tercatat sebagai produk intelektual dengan HAK CIPTA No. 016445 Tanggal 05 Mei 2010. Motto dari metode ini adalah "Pintar Terjemah Al-Qur'an dan Kitab Kuning 100 Jam". Memahami Tamyiz dapat dimulai dari formulasi Tamyiz itu sendiri yaitu berdasarkan analisis metodologinya dari latar belakangnya atau Madkholnya yaitu memahami bahwa peserta didik menggunakan bahasa Indonesia, serta melihat tujuan dari metode Tamyiz adalah untuk menterjemah makna Al-Qur'an secara lafziyah. 
Lalu pada pendekatannya atau (madkhol) yaitu dengan pendekatan linnasyiin (untuk non arab) yaitu memahami terjemah bahasa Arab beserta susunan kata dan menghindari lahn atau kesalahan. Kemudian setelah hasilnya distashih oleh pakar Tamyiz, ukuran tingkat keberhasilannya dapat diketahui. Di samping itu metode Tamyiz juga menggunakan lagu-lagu untuk menghafal kaidah-kaidah nahwu shorof.

Dimana lagu merupakan ketrampilan yang berada bagian otak kanan, sebagaimana pendapat Jw. Santrock otak kanan bersifat kreatif, ${ }^{1}$ tentang otak kanan dan otak kiri menunjukkan seharus bahwa pemeluk agama Islam adalah manusia super excellent karena keseimbangan otak kanan dan otak kiri yang digunakan membaca huruf latin dari kiri dan membaca Al-Qur'an bahasa Arab dari kanan.

Metode Tamyiz membuktikan hal tersebut sebagai keseimbangan otak dan kemampuan manusia atau umat Islam. Sebelum peneliti melakukan penelitian lebih mendalam tentang metode Tamyiz ini, peneliti sempat melakukan grand tour prapenelitian ke berbagai sekolah atau lembaga pendidikan unggulan bahasa Arab seperti melakukan grand tour ke sekolah MTs Darul Rohman III Parung ${ }^{2}$, grand tour ke pembelajaran Tamyiz di sekolah Madrasah Aliyah (MAN) Al-Azhar Asy-Syarif di Srengseng Sawah Jagakarsa ${ }^{3}$, grand tour ke Pondok Pesantren Al-Qur'an Tazkiyah Insani Pengasinan Depok, dari hasil Training of Trainner (TOT) Tamyiz masih level I.

\footnotetext{
${ }^{1}$ Jhon W Santrok, Psikologi penidikan (Mc Grow Hill, 2008), 45.

2 sekolah ini unggul di bidang bahasa Bahasa Arab dan Inggris. Metode yang digunakan di sekolah ini adalah menginduk kurikulum Gontor dan salafiyah.

${ }^{3}$ Pada tahun 2016 dan 2017 telah mengikuti latihan level I dan II kemudian metode Tamyiz di Al-Azhar Asy-Syarif dari hasil wawancara menunjukkan bahwa dengan guru Bahasa Arab yang telah mengikuti program Tamyiz, penerapan metode Tamyiz tidak bisa sendiri, harus beramai-ramai, kemudian menyenangkan, mudah diingat karena dapat dilagukan, tetapi di AlAzhar Asy-Syarif tidak hanya metode Tamyiz yang diterapkan, namun tetap menggunakan metode konvensional dan media pembelajaran, sehingga tidak terukur walaupun yang pernah belajar Tamyiz ada 12 (dua belas) orang yang melanjutkan belajar ke Mesir. Di Madrasah Aliyah Al-Azhar Asy-Syarif tidak hanya belajar dengan metode Tamyiz, ditambah beban kurikulum padat dan gemuk, maka metode Tamyiz tidak dapat diulang-ulang setiap hari.
} 
Dan dari hasil grand tour di beberapa tempat di atas, sehingga penelitian ini perlu langsung ke tempat Pondok Pesantren Bayt Tamyiz Desa Sukaperma Tukdana Indramayu kelas khusus. Di mana Metode Tamyiz telah menunjukkan prestasi siswa pintar dalam terjemah Al-Qur'an dan kitab Kuning yang terukur dan terus-menerus selama enam bulan. Belajar bahasa Arab menggunakan metode Tamyiz menimbulkan daya tarik atau minat siswa belajar dengan menarik (kohesi) sesuai prinsip Tamyiz, belajar mudah dan menyenangkan.

Oleh karena itu, penenitian ini tertarik untuk melakukan kaijian ini lebih lanjut dengan mengusung studi kasus di Pembelajaran bahasa Arab dengan metode Tamyiz di Bayt Tamyiz Desa Sukaperna Tukdana Indramayu.

\section{B. Strategi Daya Tarik (Kohesi) Pembelajaran Bahasa Arab}

1. Strategi dalam Menciptakan Daya Tarik Pembelajaran

Senada dengan konsepsi bahwa kualitas pembelajaran selalu terkait dengan penggunaan metode pembelajaran yang optimal untuk mencapai tujuan pembelajaran, di bawah kondisi pembelajaran tertentu, sebagaimana disebutkan diatas. Sehingga penciptaan daya tari pembelajaran harus dimulai dari penggunaan metode yang terbukti efektif dan relevan dengan pembelajaran yang ada.

Metode pembelajaran didefinisikan sebagai cara-cara yang berbeda untuk mencapai hasil pembelajaran yang berbeda di bawah kondisi yang berbeda. Metode pembelajaran ini diacukan sebagai cara-cara yang dapat digunakan dalam kondisi tertentu untuk mencapai hasil pembelajaran yang diinginkan. Cara-cara ini disebut juga sebagai strategi pembelajaran. Variabel metode atau strategi pembelajaran ini merupakan variabel yang paling esensial akan keberadaan pembelajaran.

Karena variabel kondisi dan variabel tujuan merupakan variabel yang tidak bisa diubah dan harus diterima sebagai barang jadi, dan selanjutnya dipakai sebagai pijakan kerja. Peluang yang tinggal hanyalah bagaimana bagaimana memanipulasi variabel metode pembelajaran untuk mencapai hasil pembelajaran yang diinginkan. Variabel metode pembelajaran diklasifikasi menjadi tiga jenis, yaitu: (1) strategi pengorganisasian, (2) strategi penyampaian, dan (3) strategi pengelolaan. 
Strategi pengorganisasian pembelajaran adalah metode untuk mengorganisasi isi bidang studi yang telah dipilih untuk pembelajaran. Mengorganisasi mengacu pada suatu tindakan seperti pemilihan isi, penataan isi, pembuatan diagram, format, dan lainnya yang setingkat dengan itu. Strategi pengorganisasian pembelajaran lebih lanjut dapat dibedakan menjadi dua jenis, yaitu: strategi makro dan strategi mikro.

Strategi makro: mengacu kepada metode untuk mengorganisasi isi pembelajaran yang melibatkan lebih dari satu konsep, atau prosedur, atau prinsip. Strategi mikro: mengacu kepada metode untuk mengorganisasi isi pembelajaran yang berkisar pada satu konsep, atau prosedur, atau prinsip. Strategi makro berurusan dengan bagaimana memilih, menata urutan, membuat sintesis, dan rangkuman isi pembelajaran (apakah konsep, prinsip, atau prosedur) yang saling berkaitan.

Pemilihan isi, berdasarkan tujuan pembelajaran yang ingin dicapai, mengacu kepada penetapan konsep-konsep, atau prinsip-prinsip, atau prosedur-prosedur yang diperlukan untuk mencapai tujuan itu. Penataan urutan isi mengacu kepada keputusan untuk menata dengan urutan tertentu konsep-konsep, atau prinsip-prinsip yang akan diajarkan.

Pembuatan sintesis mengacu kepada keputusan tentang bagaimana cara menunjukkan keterkaitan di antara konsepkonsep, atau prinsip-prinsip. Pembuatan rangkuman mengacu kepada keputusan tentang bagaimana cara melakukan tinjauan ulang konsep-konsep, atau prinsip-prinsip serta kaitan-kaitan yang sudah diajarkan.

Pertama, strategi penyampaian isi pembelajaran merupakan komponen variabel metode untuk melaksanakan program pembe-lajaran. sekurang-kurangnya ada dua fungsi dari strategi ini, yaitu: (1) menyampaikan isi pembelajaran kepada pelajar, dan (2) menyediakan informasi/bahan-bahan yang diper-lukan pebelajar untuk menampilkan unjuk-kerja (seperti latihan dan tes). Strategi penyampaian mencakup lingkungan fisik, Guru, bahan-bahan pembelajaran, dan kegiatankegiatan yang berkaitan dengan pembelajaran. Atau, dengan kata lain, media merupakan satu komponen penting dari strategi penyampaian pembe-lajaran. Itulah sebabnya, media pembelajaran merupakan bidang kajian utama strategi ini. 
Kedua, strategi pengelolaan pembelajaran merupakan komponen variabel metode yang berurusan dengan bagaimana menata interaksi antara pebelajar dengan variabel-variabel metode pembelajaran lainnya. Strategi ini berkaitan dengan pengambilan keputusan tentang strategi pengorganisasian dan strategi penyampaian mana yang digunakan selama proses pembelajaran.

Paling tidak ada empat klasifikasi penting variabel strategi pengelolaan, yaitu: (1) penjadwalan, (2) pembuatan catatan kemajuan belajar, (3) pengelolaan motivasi, dan (4) kontrol belajar. Penjadwalan penggunaan strategi pembelajaran mengacu kepada kapan dan berapa kali suatu strategi pembelajaran atau komponen suatu strategi pembelajaran dipakai dalan suatu situasi pembelajaran.

Pembuatan catatan kemajuan belajar mengacu kepada kapan dan berapa kali penilaian hasil belajar dilakukan, serta bagaimana prosedur penilaiannya. Pengelolaan motivasional mengacu kepada cara-cara yang dipakai untuk meningkatkan motivasi belajar pebelajar. Kontrol belajar mengacu kepada kebebasan pebelajar dalam melakukan pilihan tindakan belajar.

2. Indikator Daya Tarik Pembelajaran

Variabel penting yang dapat digunakan sebagai indikator daya tarik pembelajaran adalah penghargaan dan keinginan lebih (lebih banyak atau lebih lama) yang diperlihatkan oleh siswa. Kedua indikator ini dapat dikaitkan, baik pada bidang studi, maupun pada pembelajaran. Penghargaan dan keinginan untuk lebih banyak mempelajari isi bidang studi, merupakan hasil pembelajaran yang bukan hanya disebabkan oleh daya tarik bidang studi, tetapi terutama disebabkan oleh kualitas pembelajaran yang mampu memciptakan penghargaan dan keinginan itu. Oleh karena itu, maka titik awal pengukuran daya tarik, sebagai hasil pembelajaran, haruslah diletakkan pada variabel metode pembelajaran: strategi pengorganisasian, penyampaian, dan pengelolaan pembelajaran. Variabel inilah yang paling menentukan kualitas pembelajaran secara keseluruhan. 


\section{Guru Dan Teman Sebaya Sebagai Kontributor Bersama}

Guru dan teman sebaya atau sekelas dapat memberi kontribusi bersama untuk pembelajaran murid. Ada empat alat untuk melakukan metode ini yakni scaffolding, pelatihan kognitif (cognitive apprenticeship), tutoring dan pembelajaran kooperatif.

\section{Scafolding}

Scaffolding sebagai teknik mengubah level dukungan di sepanjang jalannya sesi pengajaran. Orang yang lebih ahli guru atau teman sesama murid yang lebih pandai menyesuaikan jumlah bimbingan dengan kinerja murid. Setelah kompetensi murid meningkat bimbingan dikurangi. Para peneliti menemukan bahwa Scaffolding dipakai oleh guru dan teman sebaya dalam pembelajaran kolaboratif murid akan terbantu dalam proses belajarnya.

\section{Pelatihan Kognitif}

Pelatihan Kognitive (cognitive aprenticeship) yang berarti bahwa pakar memperluas dan mendukung pemahaman pemulangan menggunakan keahlian kultur. Pelatihan positif guru sering kali memberi contoh strategi kepada murid kemudian guru atau teman yang lebih ahli membantu usaha murid tersebut untuk melaksanakan tugas terakhir mereka mendorong murid itu untuk melanjutkan tugasnya secara mandiri. Untuk mengekspresikan arti penting pelatihan kognitif dalam pembelajaran Runoff, mendeskripsikan pengalaman yang berbeda dari murid dari keluarga berpendapatan menengah dan keluarga miskin banyak orang tua kelas menengah telah melibatkan anak-anaknya dalam pelatihan kognitif sebelum mereka masuk TK atau SD. Aspek fungsi dari latihan kognitif adalah evaluasi ahli atas Kapan seorang pembelajar sudah siap diajak langkah selanjutnya.

\section{Tutoring}

Tutoring pada dasarnya adalah pelatihan kognitif antara pakar dengan pola tutoring bisa terjadi antara orang dewasa dan anak-anak atau antara anak yang ditandai dengan anak yang kurang pandai tutoring individual adalah strategi yang efektif yang menguntungkan banyak murid terutama mereka yang kurang pandai dalam suatu mata pelajaran touring bisa disebut pembantu kelas sukarelawan dan mentor sukarelawan pembantu kelas dan mentor dapat membantu mengurangi kesulitan belajar. 
Beberapa program tutoring individual telah dikembangkan ada program reading recovery sukses for all dikembangkan oleh Robert slavin 1996 program ini mencakup program membaca sistematis yang menekankan pada perkembangan kosakata dan membaca dan kegiatan bercerita di dalam kelompok kecil periode membaca selama 90 menit setiap hari dimana murid dari grup pertama sampai tiga dikelompokkan kembali dengan anak yang berkemampuan sama masukkan dalam satu kelompok terlepas dari usianya tutoring membaca yang diberikan oleh guru ahli dan terlatih yang bekerja secara individual dengan murid yang kemampuan membacanya di bawah rata-rata pengembangan profesional untuk guru dan tutor yang mencakup tiga hari training dan bimbingan pada awal tahun ajaran dan training lanjutan sepanjang tahun itu.

4. Tutor Teman Sebaya

Tutor teman sebaya adalah sesama siswa juga dapat menjadi tutor yang efektif dalam tutoring teman sebaya atau seorang murid mengajar murid lainnya. Biasanya dalam mengajar, teman yang mengajar biasanya lebih tua usianya. Dalam tutoring teman-sebaya, biasanya teman sekelasnya. Para peneliti telah menemukan bahwa tutoring teman sering kali membantu prestasi murid mengajari orang lain tentang sesuatu adalah cara terbaik untuk belajar.

Training tutor teman ini menekankan pada upaya membantu murid untuk berlatih membaca dengan suara keras, teks naratif, mereview, dan mengurutkan pembacaan informasi, meringkas materi bacaan yang banyak, mengemukakan ide utama, memprediksi dan mengecek hasil cerita, dan strategi membaca lainnya. Murid dalam kelas tutoring teman menunjukkan kemajuan membaca yang lebih besar ketimbang mereka yang tidak mendapatkan tutoring. 


\section{Sketsa Metode Tamyiz}

1. Historisitas Singkat Berdirinya Metode Tamyiz

Tamyiz adalah sebuah nama yang dikukuhkan sebagai penghormatan kepada penemu metode ini yaitu almarhum Kyai Anas Tamyiz. Metode Tamyiz ini dikembangkan oleh keponakan beliau yakni Ustadz Zaunal Fatin, terkenal dengan nama Abah Zaun atau Abaza. ${ }^{4}$

Tamyiz berdiri berawal dari pengaduan seorang bapak ke Abaza tentang anaknya yang tidak berminat melanjutkan sekolah SMA, padahal orang tuanya ingin anaknya berijazah SMA. Abaza bercanda, "ya sudah, mesantren saja di rumah saya, nanti saya kasih ijazah." Ternyata orang tersebut menganggap ucapan Abaza itu serius. Besoknya langsung membawa anaknya dengan beberapa perbekalan untuk diserahkan ke Abaza. Betapa kagetnya Abaza. "Nanti tinggal dimana? Saya tidak punya pesantren?" "Katanya bisa nyantri di rumah Abah, dan dikasih ijazah."

Akhirnya diterima, anak lelaki tersebut "nyantri" di rumahnya. Selama 3 hari anak itu tinggal di rumah, tidak diajari apapun, sebab Abaza juga tidak tahu apa yang harus diajarkan. Akhirnya di hari ke 4, Abaza mengajari anak tersebut dengan ilmu yang pernah diajarkan oleh pamannya Kyai Anas Tamyiz waktu kecil di sebuah tajug (mushola) kampung halamannya di Tukdana Sukaperna Indramayu. Genap 1 (satu) bulan belajar, anak SMA yang tidak punya background bahasa arab itu, ternyata sudah bisa menerjemah Al-Quran.

Abaza takjub dengan kemampuan anak tersebut. Tapi rasa takjubnya berubah jadi kaget, saat melihat anaknya yang usia 7 tahun pun bisa. Anaknya ini memang selalu ikut kalo ayahnya mengajari anak SMA tadi. Akhirnya, Abaza mulai berpikir bahwa yang hebat itu adalah metodenya, untuk itulah dilakukan penelitian.

Dikumpulkan sekitar 11 anak tetangga yang mau belajar Tamyiz. Lalu diajarkan Tamyiz selama 2 minggu, kemudian dites, dan hasilnya, anak-anak itu bisa menterjemah Al-Qur'an.

\footnotetext{
${ }^{4}$ Sumber : tamyiz online
} 
Kemudian diajarkan Tamyiz lanjutan selama 2 bulan. Setelah itu di tes untuk baca kitab kuning (arab gundul). Dan alhamdulillah bisa, bahkan ketika didatangkan seorang ahli bahasa Arab yaitu DR. M. Akhsin Sakho (anggota tim terjemah Al-Qur'an versi DEPAG) untuk melakukan test terhadap anakanak ini, beliau terkagum-kagum.

Abaza menulis buku Tamyiz berdasarkan hasil riset dengan mengembangkan pengalaman waktu kecil mengaji selepas isya dengan metode yang mudah dan menyenangkan menggunakan kitab Jurmiyyah yang dipraktekkan langsung ke dalam Al-Qur'an di Tajug (mushalla) at-Tamyizy di kampung Indramayu. ${ }^{5}$ Buku Tamyiz ini merupakan hasil riset penulisnya di Tajug Kampung Indramayu yang ditulis berdasarkan pengalaman mengaji di masa kecilnya kepada K. Anas Tamyiz di tajug yang sama.

2. Visi, Misi serta Tujuan Metode Tamyiz

a) Visi Tamyiz : sedari kecil pintar tarjamah Al-Qur'an dan Kitab Kuning

b) Misi Tamyiz : menjadi media belajar yang mudah untuk membentuk keluarga muslim yang sejak usia kanakkanak tidak saja dapat membaca Al-Qur'an, tetapi juga dapat mentarjamah dan menulis (imla') Al-Qur'an ketika membaca dan mendengarnya serta mampu mengajarkannya.

c) 24 jam belajar, pintar tarjamah Al-Qur'an (Tamyiz 1) 100 Jam belajar, pintar kitab kuning (Tamyiz 2) Pintar tarjamah dan kitabah (imla') Al-Qur'an dan Kitab Kuning (Tamyiz 3).

5 Abaza, Tamyiz, Pintar Terjemah Al-Qur'an dan Kitab Kuning, cet. Ke-12, Edisi Revis, (Indramayu : Yayasan Tamyiz, 2018), x. 
Belajar bahasa bukanlah sebuah ilmu pengetahuan, akan tetapi sebuah ketrampilan sehingga lebih tepatnya dengan menggunakan cara berlatih secara terus menerus atau diulang-ulang selama kurun waktu dengan bimbingan guru atau tutor yang mahir.

Demikian yang dilakukan oleh metode tamyiz ( cara membaca dan menerjemah Al-Qur'an dan kitab kuning, yang diajarkan di Pesantren Bayt Tamyiz Indramayu, kepada santri secara intensif dan terus menerus pada tahun ajaran baru sebelum diajarkan mata pelajaran yang lain.

3. Prinsip-prinsip Tamyiz

Pertama, prinsip umum, tamyiz adalah berdasarkan salah satu riwayat yang mengatakan bahwa :

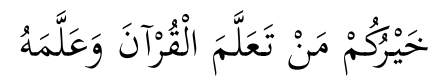

Artinya : "Orang yang terbaik di antara kalian adalah orang yang belajar al-Qur'an dan mengajarkannya".

Jadi berdasarkan hadis tersebut terdapat dua prinsip umum, yaitu : laduni (teknik belajar) dan Sentot (teknik mengajar). dari:

Kedua, prinsip khusus Metode Tamyiz yaitu terdiri

a) Prinsip Mengajar dan Belajar Tamyiz

Cara (mengajar) lebih penting dari materi yang diajarkan (الطريقة أهم من المادة). Materi yang diajarkan dalam metode tamyiz hampir sama saja dengan buku-buku Nahwu-Shorof lain, yang paling penting dalam metode Tamyiz adalah cara mengajarkannya (طريقة) yang harus bisa dipelajari oleh anak kecil karena begitu mudah thariqahnya. (Anak kecil saja bisa, yang pernah kecil pasti bisa). 
b) Prinsip Cara Mengajar Tamyiz :

Mengajar dengan bahasa hati (mengajar bisa dengan mulut bisa dengan hati, dan Allah menurunkan Qur'an ke hati manusia). Mengajar dengan mematuhi tahapan (ahada 'asyara qiraatan).

Prinsip yang sangat menentukan adalah bagaimana seorang guru atau ustad mampu mengajarkannya dengan cara yang baik, sesuai standar pembelajaran tamyiz. Pembelajaran adalah sebuah transformasi dan informasi kepada otak manusia. Manusia dibekali otak oleh Allah Swt. Yang Luar biasa sebagaimana firman Allah dalam Q.S an-Nahl 78.

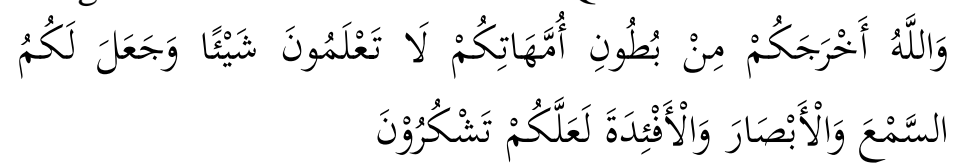

c) Prinsip Cara Belajar Tamyiz

Pertama, LADUNI (ilate kudu muni); santri belajar dengan teknik mengeraskan suaranya (sebagai salah satu cara untuk mengoptimalkan penggunaan potensi otak kiri dan otak kanan secara seimbang), ditambah dengan teknik pengulangan yang integratif (sebagai salah satu cara mengoptimalkan potensi otak bawah sadar atau qolbun/shudur) sehingga hasil belajar akan lebih optimal.

Kedua, SENTOT (Santri TOT), model belajar santri adalah ustadz yang sedang mengajar / menjelaskan kepada santri: insya Allah, santri otomatis bisa mengajarkan Tamyiz kepada orang lain (anak kecilpun sudah bisa mengajarkan tarjamah Al-Qur'an dan kitab kuning sebagaimana Ustadz/kyai mengajar santri. 
4. Mengajar dengan Bahasa Hati (Neuro Linguistic)

Ada beberapa kondisi yang harus diperhatikan dalam mengajar bahasa dengan bahasa hati :

a) Saat Delta (tidur lelap, tidak sadar, tidak berfikir) dan Theta (ngantuk, intuisi, inspiratif, dan imajintif) adalah bukan saat untuk belajar.

b) Saat Alpha (super learning, nyaman, santai, tenang, bahagia, detak jantung stabil) adalah saat menyenangkan untuk belajar.

c) Saat Beta (sadar dan beraktivitas, cemas, khawatir, waswas) adalah saat siap untuk belajar.

d) Saat Gamma (aktifitas mental tinggi, bertanding, berlomba, stress, marah) adalah saat belajar dengan otak reptilnya.

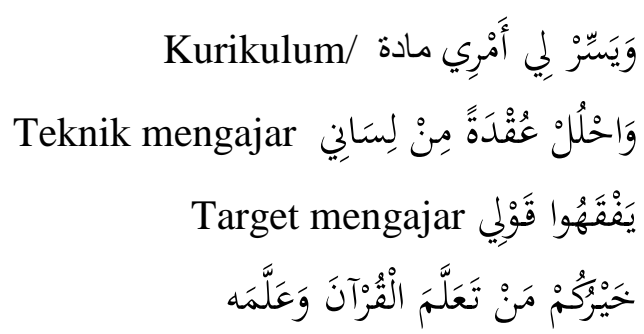

5. Prinsip Cara Evaluasi Belajar Mengajar

Pertama, mudah; proses pembelajarannya harus dirasakan mudah oleh santri, kalau ada santri yang kesulitan maka ada cara mengajar yang kurang efektif ( Tamyiz 1 dan 2 bisa dipelajari santri yang bisa membaca Qur'an walau tanpa mengerti tarjamah bahasa arab, Tamyiz 3 bisa dipelajari setelah tamat Tamyiz 1 dan 2 ).

Kedua, kesan akhir santri adalah : "Kalau hanya begitu caranya, saya juga bisa mengajarkan tamyiz." 
E. Perbedaan Metode Tamyiz Dengan Metode Pembelajaran

Bahasa Arab Yang Lain

\begin{tabular}{|l|l|}
\hline \multicolumn{1}{|c|}{ Metode Tamyiz } & \multicolumn{1}{c|}{ Metode Lain } \\
\hline Bahasa adalah keterampilan & $\begin{array}{l}\text { Bahasa dianggap sebagai } \\
\text { ilmu pengetahuan. }\end{array}$ \\
\hline $\begin{array}{l}\text { Mempunyai Perbendaharaan } \\
\text { Kata }\end{array}$ & $\begin{array}{l}\text { Tidak Mempunyai } \\
\text { Perbendaharaan Kata }\end{array}$ \\
\hline $\begin{array}{l}\text { Tujuannya bisa membaca dan } \\
\text { menterjemah }\end{array}$ & $\begin{array}{l}\text { Tujuan untuk menghindari } \\
\text { kesalahan membaca }\end{array}$ \\
\hline $\begin{array}{l}\text { Metode Menggunakan bahasa } \\
\text { Indonesia }\end{array}$ & Menggunakan bahasa Arab \\
\hline Pembelajaran system TOT & Tidak ada system TOT \\
\hline
\end{tabular}

Ini yang membedakan dengan pembelajaran Bahasa Arab Selama ini, bahwa pembelajaran Bahasa Arab (nahwu dan sharaf) yang berjalan selama ini kurang adanya penekanan terhadap tadribat yang telah diajarkan 


\section{F. Apresiasi tentang Metode Tamyiz}

Salah seorang cendekiawan yang mengakui dan menyetujui metode Tamyiz melalui uji coba dan mentashhihnya adalah DR. Akhsin Sakho Muhammad al Hafidz, MA. (Rektor Institut Ilmu Qur'an Jakarta dan Sekretaris Lajnah Pentashih Qur'an Departemen Agama RI tahun 2010). Metode Tamyiz dan santri cilik Bayt Tamyiz telah diuji shahih kemampuan menterjemahkan Al-Qur'an dan Kitab Kuning secara terbuka (tashhih) di Indramayu pada 10 Januari 2010. Hasil uji shahihnya semua santri cilik mendapat nilai mumtaz (memuaskan). ${ }^{6}$ Berdasarkan Hasil Riset metode Tamyiz :

1) Anak kecil sejak kelas $1 \mathrm{SD} / \mathrm{MI}$ bisa pintar Al-Qur'an dan Kitab Kuning. Waktu belajarnya relatif singkat, yakni 100 jam belajar.

2) Anak kecil usia 7-12 tahun sudah biasa mengajarkan terjemah Al-Qur'an dan kitab kuning sebagaimana ustadz dan kyai mengajar santri. ${ }^{7}$

3) Anak yang sudah lulus Tamyiz, bisa mengajarkan Al-Qur'an dan Kitab Kuning, termasuk anak yang masih kecil.

Hasil riset tersebut sangat mengejutkan karena berhasil menembus persepsi psikologis yang menyatakan bahwa:

1) menterjamahkan Qur'an dan Kitab Kuning (ilmu nahwu dan shorof ) hanya bisa dipahami oleh santri remaja dan orang dewasa;

2) mempelajarinya butuh waktu yang lama atau bertahun-tahun;

3) mengajarkannya harus dilakukan oleh ustadz atau kyai.

${ }^{6}$ Radar Indramayu \& Mitra Dialog Cirebon, Republika, Tahun 2010.

${ }^{7}$ Abaza, Tamyiz, Pintar Terjemah Al-Qur'an dan Kitab Kuning, cet. Ke-12, Edisi Revis, (Indramayu : Yayasan Tamyiz, 2018), i. 


\section{G. Keunggulan Metode Tamyiz}

Salah satu motivasi serta stimulasi ditemukannya sebuah metodologi baru adalah-dengan merasa tidak puas dengan beberapa metode yang berkembang sehingga harus ada upaya untuk merekonstruksi atau justru melakukan inovasi baru dalam merumuskan metodologi. Termasuk metode Tamyiz-lahir ditengah-tengah diversitas metodologi dalam hal mempelajari bahasa Arab. ${ }^{8}$ Adapun beberapa keunggulan dari metode ini adalah sebagai berikut :

1) Tamyiz memberikan kunci-kunci yang strategis untuk kedua teori tersebut, dan santri bisa langsung membaca, menguraikan struktur kata sekaligus menterjemahkan AlQur'an dan kitab kuning.

2) Tamyiz merupakan formulasi teori Quantum Nahwu-Shorof linnaasyiin dengan cara pembelajaran yang mudah dan menyenangkan dan sudah dimodifikasi sesuai dengan latar belakang santri Indonesia.

Tamyiz merupakan sebuah metode yang mampu membuat santri dan siapa pun yang bisa membaca Al-Qur'an bisa langsung pintar membaca, menguraikan struktur kata dan kalimat sekaligus menerjemahkan Al-Qur'an dan kitab kuning dengan pendekatan struktur satuan bahasa dimulai dari yang lebih kecil yaitu abjad, lafadz/kalimah sampai yang lebih besar yaitu kalam/jumlah (struktur yang bertahap) dalam waktu kurang lebih 100 jam belajar atau tidak perlu bertahun-tahun untuk bisa membaca kitab kuning. Papar Kyai Ahsin seusai mentashih santri cilik usia 7-12 tahun di Bayt Tamyiz. ${ }^{9}$

${ }^{8}$ Doktor Akhsin menjelaskan :"Kendala yang dihadapi santri selama ini adalah sulitnya memformulasikan teori nahwu-shorof dengan cara pembelajaran yang mudah, karena nahwu-shorof terlanjur dipersepsikan sebagai pelajaran yang sulit". Kendala tersebut adalah : (1) Harus belajar membaca kitab nahwu dan shorof, (2) Harus belajar menterjemahkan kitab tersebut, (3) Harus belajar memahami teori kitab tersebut, (4) Harus belajar mengaplikasikan teori kitab tersebut pada kitab kuning lain; dan (5) Bahkan, dalam kitab tertentu harus menghapal matan dan nadzom.

9 Abaza, Tamyiz, Pintar Terjemah Al-Qur'an dan Kitab Kuning, cet. Ke-12, Edisi Revis, (Indramayu : Yayasan Tamyiz, 2018), ii. 


\section{H.Sekilas Ilustrasi Materi Pembelajaran Metode Tamyiz}

Contoh materi pembelajaran dengan menggunakan metode Tamyiz berikut disertai pembelajaran dengan tutorial, hal ini yang dilakukan oleh siswa harus sama ketika disaat mereka bergiliran menjadi :

1) Pelatihan kognitif guru (pelatihan positif guru sering kali memberi contoh strategi kepada murid kemudian guru atau teman yang lebih ahli membantu usaha murid tersebut untuk melaksanakan tugas terakhir mereka mendorong murid itu untuk melanjutkan tugasnya secara mandiri).

2) Tutoring (pembantu kelas sukarelawan dan mentor sukarelawan,

3) Tutor teman sebaya.

a) Sebagai ilustrasi perhatikan Pembelajaran materi tentang "Huruf" berikut : ${ }^{10}$

Ustadz/ah menjelaskan perbedaan kata dan kalimat dalam bahasa Indonesia dan bahasa Arab. Guru membuat tulisan dalam bahasa Indonesia "itu kitab" dan tulisan dalam bahasa Arab "haadzaa kitaabun"

Anak-anak coba perhatikan yang mau ustadz/ah tuliskan...

Itu kitab...

Itu kitab... apakah kata atau kalimat...

Itu kitab... dalam bahasa Indonesia adalah 1 kalimat yang terdiri dari 2 kata

Kalimat adalah gabungan dari beberapa kata...

Anak-anakcoba perhatikan yang mau ustadz/ah tuliskan... Haadzaa kitaabun..

Haadzaa kitaabun.. apakah kata atau kalimat..

Haadzaa kitaabun.. dalam bahasa Arab adalah 1 jumlah yang terdiri dari 2 kalimat

Jadi ada perbedaan istilah dalam bahasa Indonesia dengan bahasa Arab...

Kata (bahasa Indonesia)... Bahasa Arabnya adalah kalimat...

Kalimat (bahasa Indonesia)... Bahasa Arabnya adalah jumlah...

${ }^{10}$ Selain pembelajaran huruf, masih ada tentang metode pembelajaran yang lain seperti : Pembelajaran Isim dan pembelajaran modhore. 


Guru memberi contoh lain, seperti

bismillaahirrahmaanirrahiim, dalam bahasa Arab bismillaahirrahmaanirrahiim adalah jumlah yang terdiri dari beberapa kalimat, dan tarjamahnya adalah "dengan menyebut nama Allah yang maha pengasih lagi maha penyanyang" dalam bahasa Indonesia adalah kalimat yang terdiri dari beberapa kata.

Guru menjelaskan bahwa Al-Qur'an menggunakan bahasa Arab yang kalimatnya hanya terdiri dari 3 macam kata yaitu huruf, isim dan fi'il.

Anak-anak Al-Qur'an itu diturunkan Allah dengan menggunakan bahasa Arab...

Kalimat dalam Al-Qur'an sangat sedikit yaitu hanya 3 macam...

Yaitu huruf.. isim.. dan fi'il

Coba ikuti ustadz/ah dengan suara lantang...

Huruf.. isim.. fi'il..

Huruf.. isim.. fi'il..

Huruf.. isim.. fi'il..

3 macam sedikit atau banyaaak...

Sekarang mari kita buka buku tamyiznya halaman $23 . .$.

Ikuti pak ustadz/ah yaa...

Alkalimatu immaa harfun, waimmaa ismun, waimmaa fi'lun..

Kalimat itu bisa berupa huruf, isim, dan fi'il..

Alharfu yu'rofu bihifdzhi..

Huruf diketahui dengan menghapalnya..

Alismu yu'rofu bialaamaatihi watashriifihi.

Isim diketahui dengan ciri-cirinya dan tashrifnya. .

Alfi'lu yu'rofu bialaamaatihi watashriifihi.

Fi'il diketahui dengan ciri-cirinya dan tashrifnya...

Ulang 3 kali atau sampai suasana kelas terbiasa mengucapkannya dengan suara lantang. 
Ustadz/ah menjelaskan cara membaca Al-Qur'an dalam belajar metode tamyiz adalah metode membaca AlQur'an putus-putus di setiap kalimatnya (huruf, isim dan fi'il) Anak-anak supaya kita lebih mudah membedakan mana huruf, mana isim dan mana fi'il saat kita membaca AlQur'an..

Mari kita perhatikan cara baca Al-Qur'an dengan metode tamyiz..

Ustadz/ah mencontohkan membaca Al-Qur'an surat albaqoroh ayat 2-3 dengan metode tajwid (sambung) dan diikuti membaca Al-Qur'an dengan metode tamyiz (putusputus), Ustadz/ah meminta murid mengikuti atau menirukannya.

Guru menjelaskan perbedaan huruf dan abjad dalam metode tamyiz.

Abjad adalah susunan dalam hijaiyyah dari alif sampai ya (abjad hijaiyyah) yang tidak mempunyai arti atau tarjamah.

Huruf adalah susunan dalam kolom 1 sampai dengan kolom 26 dalam buku metode tamyiz yang mempunyai arti atau tarjamah.

Anak-anak apa itu huruf?

Huruf yang dimaksud dalam Al-Qur'an bukan susunan dari alif sampai ya karena itu namanya adalah abjad hijaiyyah yang tidak mempunyai tarjamah..

Huruf yang dimaksud dalam Al-Qur'an adalah susunan dalam kolom 1-26 dalam buku metode tamyiz yang mempunyai arti atau tarjamah..

Untuk mengetahui apa saja yang termasuk huruf..?

Mari kita buka buku tamyiznya halaman 24.

Sudah dibuka semuanya..?

Kalau sudah, mari kita perhatikan semua huruf yang ada di lembaran huruf tersebut.

Apabila anak-anak hafal semua huruf yang ada di lembaran huruf itu, maka anak-anak bisa hapal semua huruf yang ada di Al-Qur'an, mauuu..? 
Guru membacakan dan menyanyikan susunan huruf dari kolom 1 sampai dengan kolom 26. Murid mengikuti seusai arahan guru.

Anak-anak mari kita belajar huruf...

Lihat kolom 1 dan ikuti ustadz/ah.

Kolom 1.. Bijari..

Bi,ka,li,la dst...

Ulang-ulang sampai lancar, setelah lancar, teruskan dengan menggunakan irama tertentu yang cocok berulangulang sampai lancar.

Setelah murid selesai menyanyikan huruf kolom 1-26, ustadz/ah membimbing Latihan praktek mengidentifikasi huruf pada Al-Qur'an surat albaqoroh ayat 2.

Ustadz/ah membaca ayat dengan metode membaca putus-putus, murid mengikuti arahan sesuai ustadz/ah.

Ustadz/ah meminta murid untuk menghitung ada berapa jumlah huruf yang ada pada ayat tersebut.

Anak-anak mari praktek mencari huruf..

Kita buka surat Al-Baqarah ayat 2 .

Sudah dibuka..?

Mari kita baca sama-sama dengan suara lantang..

Sekarang untuk memudahkan memahami mencari huruf, ustadzlah akan membaca Al-Qur'an dengan metode tamyiz yaitu membaca Al-Qur'an putus-putus..

Dengarkan dulu, lalu ikuti ustadz/ah.

$$
\text { ذلك الكتاب لا ريب فيه هدى للمتقين () }
$$

Coba dihitung ada berapa huruf dari kolom 1-26 yang ada pada ayat tersebut.

Ada berapa hurufnya...

Mari kita cari sama-sama..

ذلك huruf bukan?...

Ada di kolom berapa...

Saudanya apa...

Kalau huruf tolong diberi tanda lingkaran pada ayatnya dan tanda contreng pada kolomnya..

Sudah dilingkarin dan dicontreng..

Mari sekarang ikuti mantranya..

إشارة huruf... saudaranya ذلك 
الكتاب huruf bukan?...

Ada di kolom berapa..

Kalau bukan huruf mari sekarang ikuti mantranya..

bukan huruf pasti lainnya

У huruf bukan?..

Ada di kolom berapa..

Saudaranya apa...

Kalau huruf tolong diberi tanda lingkaran pada ayatnya dan tanda contreng pada kolomnya.

Sudah dilingkarin dan dicontreng..

Mari sekarang ikuti mantranya..

y huruf saudaranya banyak.

(لا بززم، لا نفي، لا نصب لنكرة)

Ustadz/ah membimbing mengidentifikasi huruf pada ayat 3-5 al-Baqarah dengan cara yang sama tetapi dengan menunjuk salah seorang murid memimpin menggantikan Ustadz/ah dengan bimbingan Ustadz/ah.

Ustadz/ah selalu mengingatkan siswa untuk memberi tanda lingkaran dan contreng pada setiap huruf yang ditemukan.

Demikian sekilas ilustrasi tentang proses belajar mengajar, khusnya dalam pembelajaran "huruf" dengan metode Tamyiz terus dikembangkan oleh penemu metode Tamyiz ini dari waktu ke waktu. 
Kohesi Metode Tamyiz dalam Pelajaran Bahasa Ara6 di Pesantren Takhassus Bayt Tamyiz Indramayu |

\section{Deskripi Lampiran Pembelajaran}

\section{Tabel : Huruf}

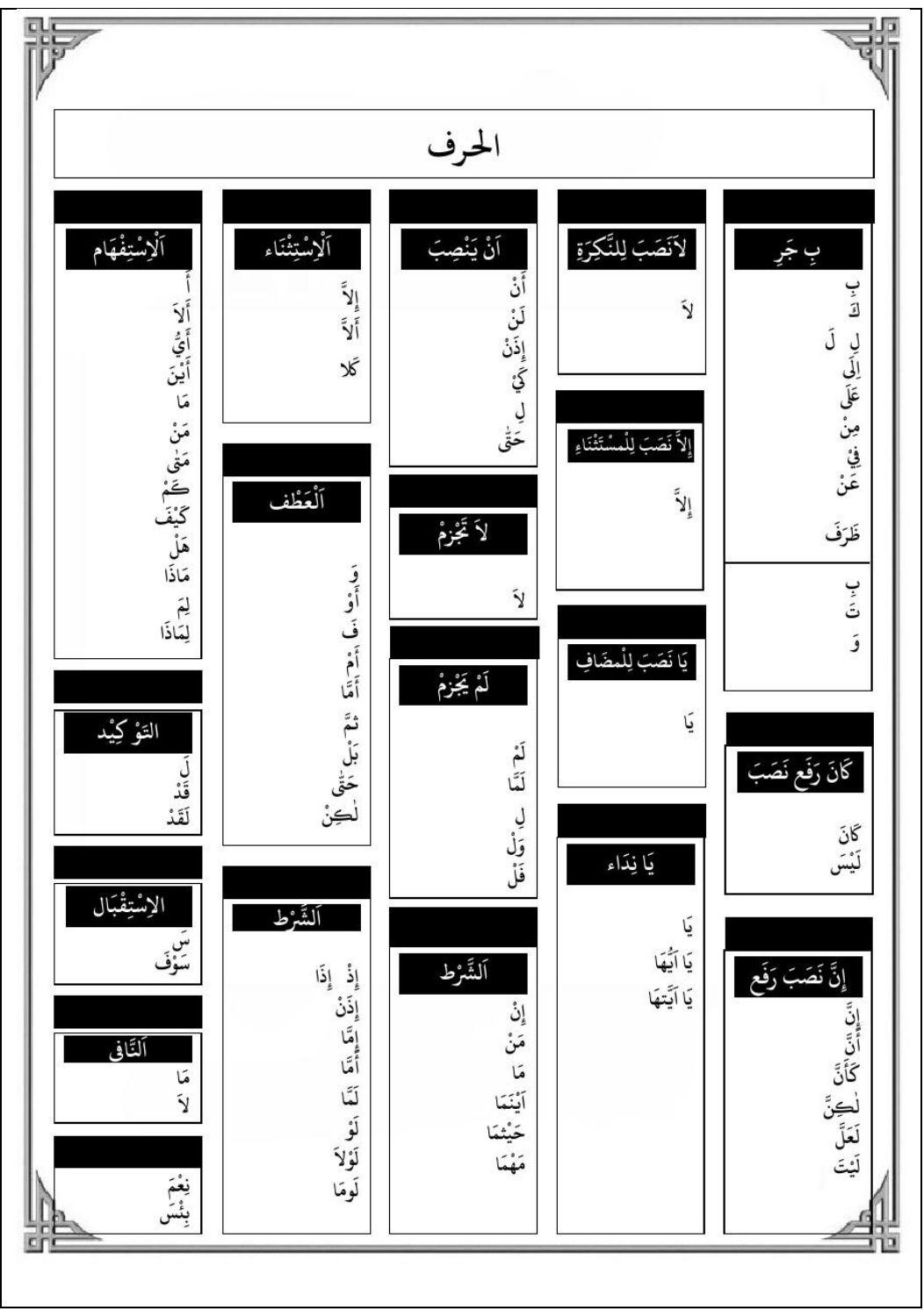




\section{Tabel : Ma'rifah}

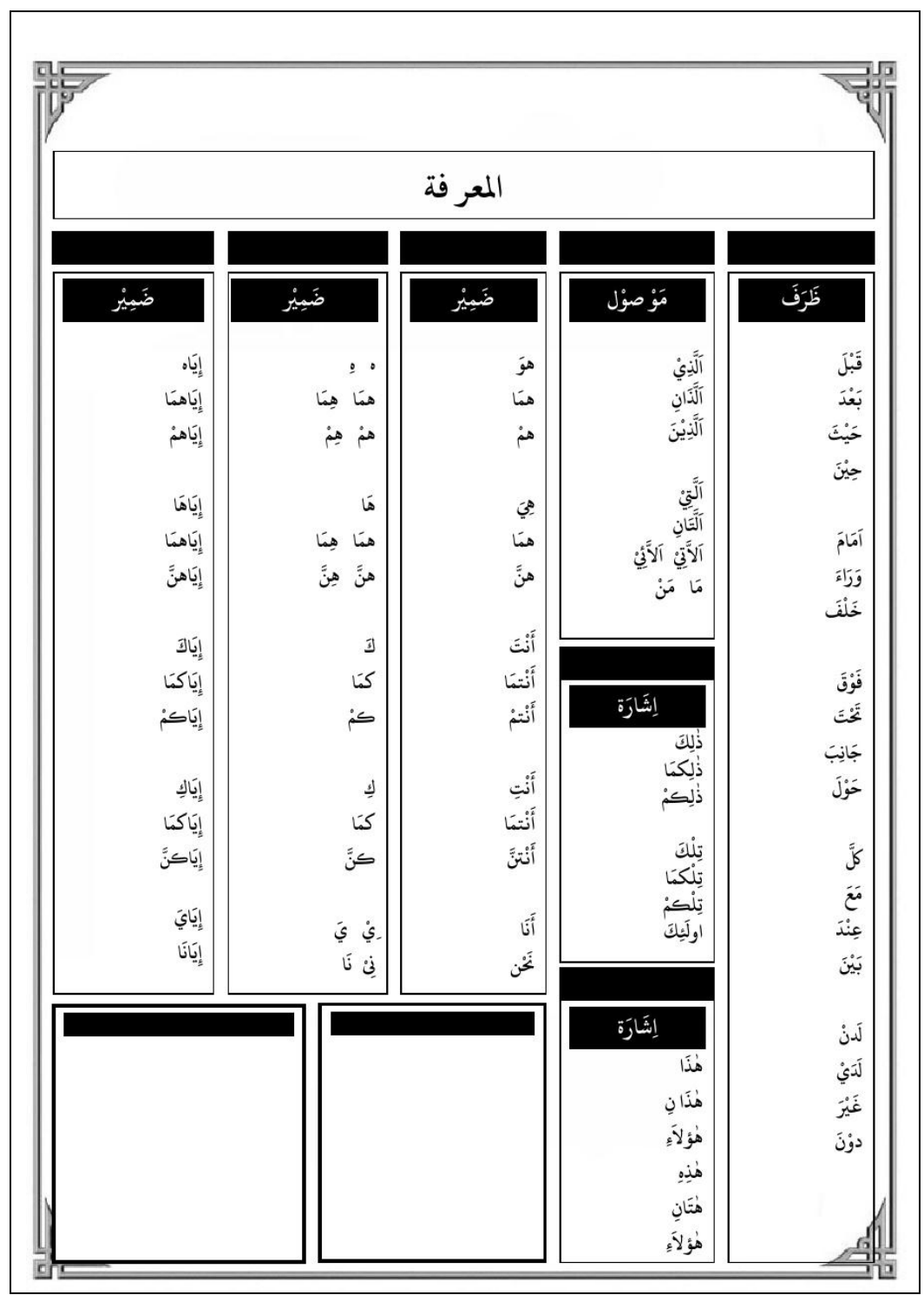




\section{J. Penutup}

Berdasarkan pembahasan hasil penelitian peneliti menyimpulkan bahwa kohesi pembelajarn Tamyiz adalah :

Pertama, Menghadirkan guru ada bentuk stimulus yang dibuat dari guru sehingga murid mudah belajar menghafal. Laduni: bahasa ibu yang meniru bahasa asing. Kudu Muni (Harus Bunyi), Metode guru-mikir banyak jadi susah, Metode tamyiz yang dikedepankan-meniru dan mengulang, berfikir dan menghafal. Pembelajaran cepat dimengerti, cepat masuk dengan bernyanyi bersama belajarnya enjoy, happy, santai.

Kedua, Tamyiz unik tidak ada ijazah, dikatakan mampu adalah dengan mengajarkan kepada kelas di bawahnya dengan monev dari Ustadz. Bahkan jika sudah pulang ke lembaga masing masing jika dirasa masih kurang harus kembali ke bayt Tamyiz. Lalu belajar dan mengajar.

Keempat, Otak bawah sadar. Otak kanan berfikir tidak meniru. Agar kuat harus elaborasi yang baru dan yang sudah ada di memory. Identifikasi-berfikir memakai logika. Menghafal cara bekerjanya dihafal dan diulang

Kelima, Metodologi latar belakang madkhal, manhaj, Kesulitan orang Arab memahami bahasa Arab (linnasiin).

Keenam, Tutorial sebaya atau tehnik scaffolding atau gunakan kawan sesama murid yang lebih ahli sebagai guru (teori Vygotsky)

Ketujuh, Kelas formal SMP di bagi semester kurikulum nasional pendidikan di pisah waktunya lalu tamyiz tersendiri.

Kedelapan, Metode pembelajaran Tamyiz juga diterapkan pada mata pelajaran umum lainnya.

Kesembilan, Tamyiz Icon Indramayu SK Gubernur, SK Bupati. Tetapi masih belum optimal karena tidak mengikuti sistem pembelajaran Tamyiz sesuai yang digariskan oleh penemu metode Tamyiz Abaza, MM.

Kesepuluh, Menggunakan tehnik scaffolding Tutorial sebaya atau tehnik scaffolding atau gunakan kawan sesama murid yang lebih ahli sebagai guru. Cari kesempatan untuk menggunakan teknik ini ketika murid membutuhkan bantuan untuk aktivitas yang merupakan inisiatifnya sendiri. Scaffolding untuk membantu murid naik ke level keahlian dan pengetahuan yang lebih tinggi. 
Cukup berikan bantuan yang dibutuhkan saja. Anda bisa bertanya, "apa yang bisa saya bantu?" atau cukup amati kemauan dan usaha murid, beri bantuan ringan jika diperlukan. Jika murid tampak ragu, beri dorongan. Dorong murid untuk melatih keahlian. Anda bisa mengawasi dan mengapresiasi praktik murid atau memberikan bantuan ketika murid lupa tentang apa yang mesti dilakukan.

Kesebelas, Menggunakan kawan sesama murid yang lebih ahli sebagai guru. Ingat bahwa menurut Vygotsky bukan hanya orang dewasa yang penting dalam membantu murid mempelajari keahlian. Murid juga bisa mendapat manfaat dari bantuan dan petunjuk dari temannya yang lebih ahli. "Pendekatan Konstruktivis Sosial", yang mencakup pembahasan tentang rekan sebaya sebagai murid. 


\section{Daftar Pustaka}

Abaza, Tamyiz; Anak kecil saja bisa yang pernah kecil pasti bisa pintar Tarjamah Al-Qur'an dan kitab kuning, cet. Ke 12 efdisi revisi 2018, Indramayu : Tamyiz Publising, 2018.

E-Journal.iainkendari.ac.id/al-izzah/article/view/436/411,tahun 2016.

Halim, Abdul, Muhammad, Metode Tamyiz dan Kamus Kawkaban, Purwokerto : Komunitas Tamyiz Purwokerto, 2013.

Jurnal Psikologi Islam dan Budaya, Edisi April 2018

Muhtadi, Ahmad, Pengajaran Bahasa Arab, Media dan Metodemetodenya, Yogyakarta : Sukses Offset, 2009.

Pribadi, Beny A, Model Desain System Pembelajaran, Jakarta: PT. Dian Rakyat, 2009.

Ratih, Arini Rena, Prodi PAI, Fakultas Tarbiyah Agama Islam, Univ. Muhammadiyah Surakarta, 2013.

Roscoe, R.D., \& Chi, M.T.H, Understanding tutor learning: Knowledge Building and Knowledge telling in peer tutor's explaination and questions. Review of education research, 2007.

Santrock, W. John, Psikologi Pendidikan, Prenada Media Grup, cet. ke II tahun, 2008.

Sujana, Nana, Dasar-dasar Proses Belajar Mengajar, Bandung : Sinar Baru Algesindo, 2005.

Woolfolk, A. Educational Psychology, USA: Pearson education, Inc. 2007.

Yusuf, Tayar dan Syaiful Anwar, Metodologi Pengajaran Agama dan Bahasa Arab, Jakarta : PT. Raja Grafindo Persada, 1997. 